\title{
Older and More Engaged: The Influence of an Employee's Age on Work Engagement
}

\author{
Stephanie K. Douglas \\ Embry-Riddle Aeronautical University \\ Robin A. Roberts \\ Embry-Riddle Aeronautical University
}

The workforce is aging as employees over the age of 50 are becoming the majority and are increasing the need of age in business diversity studies. Older workers are often subjected to negative stereotypes that assume less work engagement. Significantly higher work engagement was in older employees confirming the value of older employees to organizations and disputing the negative stereotypes and assumptions of the older workforce. The findings support the need for age as a component to diversity, equity and inclusion initiatives in organizations to support strategy of talent management, workforce planning, and strategic human resource recruitment.

Keywords: ageism, older worker, work engagement

\section{INTRODUCTION}

A dynamic shift in the ages of people in the workforce has gained the interest of academics and practitioners seeking to understand the forces that influence employee work engagement. The shift is that aging employees 60 years or older are remaining in the workforce past the age at which they can retire and are vastly outnumbering their junior colleagues. The U.S. Bureau of Labor Statistics estimates that $25 \%$ of the U.S. workforce will be older than 65 by 2024; a decade ago, the same group was only $11 \%$ of the U.S. workforce (Toossi \& Torpey, 2017). The National Institute for Occupational Safety and Health (NOISH) (2015) announced that by $2022,68 \%$ of people in the U.S. aged 55 to 64 are projected to participate actively in the labor force while $32 \%$ of those who are 65 to 74 years old are projected to do the same.

According to NOISH (2015), population aging is the reason for the swell of older workers remaining in the workforce, with the U.S., Japan and most of Europe leading the acceleration deemed the longevity revolution (Japan Statistics Bureau, 2013; United Nations, 2019) or age quake (Tempest et al., 2002; Veth et al., 2019). With the latter in mind, age associated with employee engagement should be prevalent in human resources and organizational development studies as population shifts will be high impact factors of employment issues like retention, employee satisfaction, organizational culture and socialization, employment relationships, talent and performance management, and career advancement (Gruman \& Saks, 2011; Avery et al., 2007; Bal \& De Lange, 2015; Kim \& Kang, 2017). 
While the age of the workforce is graying, age discrimination against older employees is still prominent. The Equal Employment Opportunity Commission found that while more than 50 years have passed since age discrimination was outlawed, negative stereotypes persist and are a significant and costly problem for workers, their organizations and the economy (Lipnic, 2018). Common negative stereotypes and misperceptions (ageism) are that older workers are poor performers, resistant to change, difficult to adapt and overall, less engaged (Posthuma \& \& Campion, 2009; Ng \& Feldman, 2010; Dordoni \& Argentero, 2015). Older workers experiencing ageism at work may incline to lower levels of work engagement (Cuddy et al., 2005; Bayl-Smith \& Griffin, 2014; Deloitte, 2014; Matos \& Galinsky, 2014). Systemic perceptions of older workers as intending to retire, withdrawing from the workforce, and identification as a late career worker have led to a stigmatized identity in the workplace that may detrimental to the employee's engagement and the organizational outcomes (Levy \& Macdonald, 2016). Despite the stereotypes and ageism, studies found employees over the age of 60 demonstrating emotional and intellectual stimulation, solid social networks, and efficacy in performance linked directly to job resources like work goals, learning and development, and team climate (Bakker \& Demerouti, 2007; James et al., 2012; Robinson et al., 2004; Towers Perrin, 2005).

The modern workforce is a cornucopia of diverse workers of a variety of ages seeking to uniquely express skills, capabilities, and social aptitudes at work (Roberts, 2020), including older workers (Avery et al., 2007; James et al., 2012; Kim \& Kang, 2017; Douglas \& Roberts, 2020). With the increase in older workers remaining in the workforce, continuing to study employees' age-related work engagement may produce evidence that lessens negative stereotyping and ageism about older employees (Tempest et al., 2002; Avery et al., 2007; Pitt-Catsouphes \& Matz-Costa, 2008; Bal \& De Lange, 2015; Kim \& Kang, 2017; Jones et al., 2018; Douglas \& Roberts, 2020). Consideration of how employee age influences work engagement contributes to practitioners' and academics' understanding of employee development, work conditions interventions, and employment agreements suitable to the shifting workforce demographics needing more empirical studying (Douglas \& Roberts, 2020). The purpose of this research was to examine the relationship between work engagement and age to contribute to the understanding of older employees' work engagement by examining age differences beyond generational stereotypes.

\section{RESEARCH QUESTION}

Determining how age contributed to work engagement facilitated the exploration in this study to answer the research question:

\section{RQ: Does an employee's age influence work engagement?}

Prevalent in contemporary organizational studies is to examine age as generational cohorts or that which describes people demographically, chronologically, and collectively by approximate age and years of birth (Ryder, 1965; Jones et al., 2018). Thus years of birth terms like Traditionalists or Veterans (pre1946), Baby Boomers (1946-1964), Generation X (1965-1977), Millennials (1977-2000), and Post Millennials $(2000+)$ are used to describe groups of people being studied within generational cohort theories that contrive social, psychological, and biological results to evidence the participants' activities (Sessa et al., 2007; Jones et al., 2018). Though studying such cohorts have produced greater understanding of shared social and life events that influenced people within the varied age ranges, the studies purporting generational nuances have been shown to be limited to a mostly Western culture perspectives varied from the same generation of people in different geographic locations (Jones et al., 2018). Additionally, generational cohort theories may breed stereotypes and ageism by assigning attributes of a sample to an entire population that is assumed to persist over time (Parry \& Urwin, 2011; Jones et al., 2018).

Better for work-related research on age and work engagement might be to examine the ages of people within the same work cohort of a variety of ages having shared experiences to reveal heuristic evidences not limited by generational concerns. With the latter in mind, this study considered assumptions about 
youth vitality powering younger employee to be more engaged in their work. Prior studies have contradicted the assumption finding older employees more engaged (James et al., 2011; Robinson et al., 2004; Towers Perrin, 2005; Hoole \& Bonnema, 2015). The outcome of this study is predicted to show that older employees will be more engaged than the younger employees (Hypothesis 1) through three dimensions of work engagement: vigor, absorption and dedication (Schaufeli et al., 2002). Assuming age influences work engagement, then age will also influence each dimension. Related to Hypothesis 1, the outcomes of this study predicted that older employees will have a higher vigor score (Hypothesis 2), a higher absorption score (Hypothesis 3) and a higher dedication score (Hypothesis 4).

\section{LITERATURE REVIEW}

Employee engagement in general has become popular in business and management literature and press as extant research has shown that employees of all ages encouraged to champion their work and working relationships, or work engagement, benefits both employees and their employers (Avery et al., 2007; Pitt-Catsouphes \& Matz-Costa, 2008). Kahn (1990, 1992) first explained employee engagement as a range of behaviors and modes employees expressed as satisfaction of the support and autonomy to authentically perform their work role. Employees perceiving full organizational support and autonomy expressed modes and behaviors demonstrating vitality. Employees perceiving they were less supported and desired more autonomy, withheld vitality and effort in their role as a demonstration of disengagement (Kahn, 1990, 1992).

\section{Work Engagement}

Work engagement is the opposite of burnout syndrome defined by high energy, strong involvement and sense of efficacy (Schaufeli \& Salanova, 2007; Maslach \& Leiter, 1997). Work engagement is the positive state of fulfillment in employees that is characterized by vigor, dedication and absorption (Schaufeli et al., 2002). Schaufeli et al. (2002) identified vigor as vitality, high energy and mental resilience that allows an individual to thrive in the face of difficulties. Dedication is characterized by enthusiasm, inspiration and the sense of significance in the work and the organization. Absorption is understood as being fully engrossed in the work or tasks. The concept of work engagement and the dimensions according to Schaufeli et al. (2002) are the most well-known and are the frame for defining work engagement in this study.

Early studies by Rousseau $(1989,1990)$ noted employee work engagement to be stimulated by reciprocal organization-employee explicit and implicit obligations. Strong work engagement reciprocity was reported to appear when organizations provided lucrative compensation, benefits and opportunities (explicit) comparable to an employee's version of life style, career aspirations, safety and well-being, and opportunities to do meaningful work (implicit) (Rousseau, 1989, 1990; Rigotti, 2009; Chalofsky \& Krishna, 2009; Kular et al., 2008; Macey \& Schneider, 2008; Shuck, 2011; Truss et al., 2013; Villegas, 2020). An employee satisfied by explicit organizational rewards would reciprocate by demonstrating vigor and dedication to performing tasks and fostering collaborative work relationships as an advocate of organizational success (Rousseau, 1989; Schaufeli \& Bakker, 2004; Rigotti, 2009; Chalofsky \& Krishna, 2009; Kular et al., 2008; Macey \& Schneider, 2008; Shuck, 2011; Truss et al., 2013, Villegas, 2020).

Jones et al. (2018) found work engagement to often be defined through the lens of generational circumstances rather than being initiated by reciprocity agreements between employers and employees (Gilleard, 2004). Generational literature proposes that members within a particular birth age continuum have the same attributes like work values (Smola \& Sutton, 2002; Cennamo \& Gardner, 2008), learning and development styles (Sayers, 2007; D'Amato \& Herzfeldt, 2008), career aspirations and outcomes

(Parry \& Urwin, 2011), personal/work time balance (Beutell \& Wig-Berman, 2008), organizational commitment (D'Amato \& Herzfeldt, 2008) and leadership personalities, styles, and behaviors (Twenge \& Campbell, 2008; Twenge, 2010). Though the goal of generational literature is to provide information for practitioners and academics to develop resources, opportunities, and work conditions that leverage employee work engagement from a generational standpoint (Lyons \& Kuron, 2013), it also raises 
concerns of stereotyping, biases, and generational profiling that can be untrue of workers within generational cohorts (Foster et al., 2003). Awarding an entire generation of a variety of workers with a wide range of experiences the same engagement attributes lacks empirical proof (Foster et al., 2003; Jones et al., 2018), is too broad, and hard to verify in a global multi-generational workforce (Jones et al., 2018). More appropriate for academics and practitioners to consider is examining employee age instead of generational cohort to best understand how the stage in life and career moderates employee work engagement since these are unalloyed and natural to the employment life cycle no matter a worker's generational status (Foster et al., 2003; Bal \& De Lange, 2015; Jones et al., 2018; Douglas \& Roberts, 2020).

Bal and De Lange's (2015) comprehensive study connecting age and stage of life to flexible human resource management and employee engagement offered evidence of job engagement in employee energy levels, devotion to work, and job performance in a variety of countries, employment arrangements, cultures, and lifespans. The study found flexible work schedules, work responsibilities, and job conditions, fostered equilibrium with employees' personal lives which in turn increased focused work and satisfaction in younger employees and higher levels of performance and productivity in older workers. The variety of geographic locations studied challenged generational stereotyping and provided more insight on age, stage of life and employee cohorts' shared experiences evidencing age-related impacts on work engagements (Bal \& De Lange, 2015).

Summarily, considering how engagement affects various aspects of an organization, understanding the relationship of age and work engagement is crucial. By continuing the examination of age and work engagement, negative stereotypes and assumptions of older employees can be dispelled. While previous studies have found older employees engaged at work, the assumptions and perceptions of older employees as less engaged still exist in organizations. Continued studies and measurements of work engagement and the influence of age are necessary to move beyond associating employees with generational cohorts to considering more aspects like conservation of resources, stage in life, and agediversity employee cohorts' shared organizational experiences. The examination of a variety of age-work engagement relationships can help practitioners and academics to better develop strategies on development and interventions of key employment outcomes such as employee retention, satisfaction, and performance management (Avery et al., 2007; Kim \& Kang, 2017; Douglas \& Roberts, 2020).

\section{Conservation of Resources Theory}

The relationship between work engagement and an employee's age is supported by the theory of as one ages, he or she acquires resources. The Conservation of Resources (COR) theory describes tangible and intangible resources collected during a person's lifespan used as discretionary assets for social and occupational endeavors (Hobfoll, 1989, 2001, 2002). Hobfoll's (1989; 2001) seminal work on COR proposed that by conserving resources, an individual assumes that a resource is scarce and must be replenished when depleted and that the type and perceived value of personal resources changes over one's lifetime. Personal characteristics (intangible) such as self-efficacy, self-esteem, optimism, hope and resilience (Bakker et al., 2011; Sweetman \& Luthans, 2010; Xanthopoulou et al., 2007) may increase as one ages and has multiple experiences.

From the COR theory, positive energy or emotions are considered resources for work engagement that act as a means to greater value (Hobfoll, 2002). The positive emotion enhances the sense of ability to control and influence one's environment (Hobfoll, 2003) which can lead to stronger work engagement (Kim \& Kang, 2017). This emotional state is a condition for abundant resources (Fredrickson, 2001) which can increase work engagement (Kim \& Kang, 2017). Using COR theory, it can be predicted that increases in emotional resources gained as one ages is likely to lead to positive outcomes for increased work engagement. Assumptions in the COR theory is that as an employee ages, he or she obtains and retains resources related to their performance at work which influences engagement and organizational affinity. 


\section{METHODS}

\section{Sample and Procedure}

The present study used a sample of 485 employees in a private sector organization in the aviation and aerospace industry. A convenience sample was used in order to control for the structure and leadership influence on the sample. Using the organization's employee database, the sample was made up of employees in the same department with the same leadership. Convenience sampling does have the advantage of being able to obtain sample selections and data collection with relative ease; however, it is important to note a convenience sample can limit generalizability and while this type of sampling technique may provide good results, caution should still be used in interpreting the data collected.

A survey instrument package via email was sent from the researchers. In total 181 participants $(\mathrm{N}=$ 181) completed the survey instrument, which included the Utrecht Work Engagement Scale (UWES) to measure employee engagement and demographic questions to collect data on age and gender, giving a response rate of 37 percent. Researchers have shown that responses obtained via traditional "paper and pencil" methods and online procedures do not vary significantly as a function of collection method (Meade et al., 2007). Reminders were sent two weeks later, followed by an email of the survey again one month after the first. This was to enhance the response rate. The study was approved by the researchers' university institutional review board. There was no required or compulsory reason to participate.

\section{Measure}

The Utrecht Work Engagement Scale (UWES) is a distinct scale developed to measure work engagement. It consists of 17 items that measure the vigor (5 items), dedication (6 items), and absorption (7 items). Respondents evaluated their work engagement by rating statements about how they felt at work with seven-point rating scales $(0=$ never to $6=$ always $)$. High scores on the full scale and all subscales indicate a high level of work engagement. Alpha coefficient from other studies ranged between 0.80 and 0.90 (Demerouti et al., 2010). Schaufeli et al. (2002) have validated the UWES in numerous countries and demonstrated support for a three-factor structure corresponding to the three dimensions and found each scale to have high reliability (Bakker et al., 2011).

Exploratory factor analysis confirmed the three-factor model as the best fit. The three-factor model provided a good fit, $\chi 2(\mathrm{df}=33)=121.68, \mathrm{p}<.001$; RMSEA $=0.07$; TLI $=.90$. All items had significant and salient loadings ranging from .32 to .93 . However, the model had very high correlations among the three factors $(.83-.93)$, raising the possibility the three factors were not distinct from one another. As a result, a single-factor model was also tested to determine if the scale was measuring a unidimensional construct. The one-factor model did not fit the data as well as the three-factor model: $\chi^{2}(\mathrm{df}=104)=$ $676.09, \mathrm{p}<.001 ; \mathrm{RMSEA}=0.18$; TLI $=.73$; therefore, the three-factor model was retained

The internal consistency of the full scale and all three subscales was computed using Cronbach's Alpha. The alpha value for the full scale was $\alpha=.90$ indicating good reliability and the alpha values for each factor were dedication $\alpha=.92$, absorption $\alpha=.79$, and vigor $\alpha=.89$.

\section{RESULTS}

To examine differences in work engagement and age, one-way ANOVA and post-hoc tests (Tukey's HSD) were conducted. The comparative tests showed that age was influential to the total work engagement score and its dimensions-vigor, dedication and absorption. Significant differences concerning work engagement and age were found. Older employees were found to have a higher work engagement score and be more vigorous, dedicated and absorbed in their work than the younger employee age groups.

A higher mean work engagement score was found in those 63 or older $(\mathrm{M}=82.53, \mathrm{SD}=12.56)$ than those 30 to 50 years of age $(M=75.26, S D=15.91)$ and those 51 to 62 years of age $(M=72.56, S D=17.96)$. Independent one way ANOVA showed a significant effect of age on work engagement $(F(2,177)=$ 1594.97, $\mathrm{p}<.001, \omega^{2}=0.06$. Post hoc testing using Tukey's correction revealed that those 63 and older 
had significantly greater work engagement scores than those 30 to 50 years of age $(p<.001)$ and those 51 to 62 years of age $(\mathrm{p}<.05)$.

\section{TABLE 1 \\ MEAN, STANDARD DEVIATION, ONE WAY ANOVA AND TUKEY'S HSD OF WORK ENGAGEMENT DIMENSIONS AND AGE GROUPS}

\begin{tabular}{lclll}
\hline Age & $\boldsymbol{N}=\mathbf{1 8 0}$ & Vigor & Dedication & Absorption \\
\hline 1. 30-50 years & 58 & $4.80(\mathrm{SD}=1.01)$ & $4.85(\mathrm{SD}=1.07)$ & $4.47(\mathrm{SD}=1.09)$ \\
2. 51-62 years & 64 & $4.65(\mathrm{SD}=1.16)$ & $4.70(\mathrm{SD}=1.17)$ & $4.32(\mathrm{SD}=1.24)$ \\
3. 63+ years & 58 & $5.24(\mathrm{SD}=0.76)$ & $5.30(\mathrm{SD}=0.84)$ & $4.98(\mathrm{SD}=0.91)$ \\
$F(2,177)$ & & $5.68^{* * *}$ & $5.76^{*}$ & $7.06^{* * *}$ \\
Tukey's HSD & & $1<3^{*}$ & $1,2<3^{* * *}$ & $1<3^{*}$ \\
& & $2<3^{* * *}$ & & $2<3^{* * *}$ \\
\hline
\end{tabular}

${ }^{*} p<.05, * * * p<.001$

\section{DISCUSSION}

The aim of this study was to examine the relationship between employee age and work engagement. Results confirmed that age is associated with work engagement supported by all formulated hypotheses $(1,2,3$, and 4). Older employees, specifically employees over the age of 63 , were found to significantly have higher work engagement scores than employees 51 to 62 years of age and 30 to 50 years of age. While the differences in mean levels of engagement within the age groups were significant, the effect sizes were relatively small. Nevertheless, the findings from this research indicated that age factored into the phenomenon of work engagement as confirmed in other studies of older employees with high work engagement (Schaufeli \& Bakker, 2004; Schaufeli et al., 2006; Haley et al., 2013; Pocnett et al., 2015; Bal \& De Lange, 2015). Implications of the results are discussed below.

\section{Practical and Research Implications}

For practitioners, the results in this study shows that age is related to employee engagement and has implications for business and employment activities and outcomes. The findings of this study should encourage HR professionals, managers and organizational practitioners to challenge assumptions that older workers may be less engaged, while working actively to understand the values they bring to an organization and to support the resources requisite for them to do their work authentically and productively. The findings of this study do not necessarily guarantee that older employees' level of work engagement will be sustained without any effort from them or organizational resourcing; nor, does the study assume that all older workers' engagement levels are high. The results proved that older workers do have the capacity to be highly engaged and therefore should be studied more to dissuade instances of ageism. Since ageism is still prevalent in organizations, such unfriendly environments may discourage older employees as age discrimination leads to lower levels of work engagement (Bayl-Smith \& Griffin, 2014). Considering fewer than half of employers provide training and programs regarding age diversity in organizational settings (Deloitte, 2014; Matos \& Galinksy, 2014), practitioners are encouraged to explore development, training, and career opportunities of workers of all ages but especially of those nearing retirement ages whose contributions may be perceived less valued or vital. Additionally, organizations should support employees in understanding differences across age groups while highlighting strengths and similarities that nurture equity and inclusion.

For researchers, the results in this study somewhat support the idea of cohort theory by considering heuristic work values congruent and unique to multi-generations of workers who collectively experience defining organizational moments impacting their work engagement rather than those of a definitive age group (Jones et al., 2018). Cohort theory encompasses organizational events being experienced 
simultaneously by workers of all ages that impose on work engagement such as organizational restructuring or catastrophic world events (Jones et al., 2018; Roberts, 2020). Cohort theorists recommend that studying cohorts and age efficacy on work engagement should be accomplished empirically, longitudinally (long time-lag) and sequentially (long but period-time lags) to account for variations, disruptions, and phenomena appearing within time and life events cyclically. Continued studies can help to review and analyze data instances of cohort heuristic experiences that may not occur in cross-sectional or snapshots of exploration.

A substantive value of cross-sectional data like in this research is to be a touchpoint of research along a time continuum that can trigger divergent perspectives to more commonly accepted research narratives, especially during times of tumultuous change. The findings in this research, for instance, triggers the need to continue evolving more work engagement research outside of generational cohorts and to focus more on organizational cohorts' work engagement contextual to industry, geography, demographics, and shared cohort experiences befitting of the shifts of worker constructs and needs in the current and emerging workforce. Cross-sectional data findings like in the present study provide concepts to explore regarding surging forces (e.g. longevity revolution) within the global work environment impacting work engagement of age-diverse work populations as is relevant in this new decade of cataclysmic changes.

Lastly, this study's results indicated that older workers' high engagement levels in vigor, dedication, and absorption are befitting of conservation of resources theory (COR). COR theory points to work engagement as a work-related outcome that can be affected by age ( $\mathrm{Ng} \&$ Feldman, 2010). COR theory purports that as people age, they secure, and retain collected resources, including those which are intangible like energy, motivation, and vitality to perform work (Hobfoll, 1989, 2001; Owens et al., 2016). Positive personal resources are proposed to enhance a person's sense of ability to control and influence his or her work attitudes and behaviors (Hobfoll, 1989, 2001) which can lead to stronger work engagement (Kim \& Kang, 2017). Conversely, a lack of or diminished resources can produce stress and disengagement of employees of any age mentally, emotionally, and energetically from their work and working relationships (Hobfall \& Shirom, 2001; Westman et al., 2004). An affirmed an emotional state that builds confidence in work tasks and relationships fosters conditions for supplying and appraising resources (Fredrickson, 2001) which can increase work engagement. The findings of this study appropriates the need for further examining the age-work engagement dyad with considerations of the dyad being moderated by COR especially during the age quake/longevity revolution (Toossi \& Torpey, 2017).

\section{STUDY LIMITATIONS AND DIRECTIONS FOR FUTURE RESEARCH}

The findings of this study influence both theory and practice regarding work engagement and employee age; however, there are still limitations to this study. While the findings are validated and valuable there are several factors which possibly limited this study. The UWES is a tool that has widely been found valid and reliable; however, there may still be a voluntary response bias. The participants who completed the study did so on a voluntary basis which adds a potential for response bias. The crosssection sample of the study was also limited to employees within the same organization. While the employees are dispersed throughout the world at multiple locations of the organization, the responses may be limited to influence from the single organization.

The results of the study are rather descriptive in character so they should be treated as a starting point to further correlational investigations. Work engagement is a complex construct of many factors which influence high and low work engagement. Those factors may belong to personal traits or the organizational environment. Or it may be related to specific job tasks assigned to the employee. Further studies should focus on many factors that are influential to work engagement as further correlational investigations.

The influence of employee age on work engagement should be studied in other industry and organization contexts beyond the scope of this study. The organizational environments may be a factor in work engagement and should be investigated for further generalizability of findings related to older 
employees being more engaged. Additional analysis such as structural equation modeling should also be performed to expand the investigation of age and work engagement. Structural equation modeling should be used in future studies to include and to estimate the influence of age on work engagement as a more reliable analysis.

\section{CONCLUSION}

The message conveyed in this research is that rather than focusing on training managers and leaders on how to manage older workers, organizations need greater emphasis on overcoming and changing the damaging perceptions that older employees are less engaged and disinterested in their work (McCann \& Giles, 2002). Older workers are often highly engaged, finding meaning and purpose in their work and whose resources can be leveraged toward organizational progress. Beliefs about aging and treatment in the workplace are documented as influential on job satisfaction, commitment, and engagement. The persistent perceptions of older employees to be a lower status group leads to mistreatment and stereotyping in the domains of job satisfaction, commitment and engagement (Roscigno, 2010; Lamont et al., 2015). Perceived age discrimination as a result of the assumptions and stereotypes of older workers influences all ages of the workers with an impact on job satisfaction, commitment and engagement (Hassel \& Perrewe, 1993: Snape \& Redman, 2003). The perception of age discrimination and concerns of aging can undermine employee performance. The social identification with an age group has been found to influence work engagement and outcomes (Bal \& Kooji, 2011; Bayl-Smith \& Griffin, 2014; Desmette $\&$ Gaillard, 2008). How an employee views their attitudes towards work and the organization will influence work engagement, satisfaction and turnover intentions (Bal \& Kooji, 2011; Hirschfeld \& Field, 2000). If age discrimination is perceived due to assumptions and negative stereotypes within the organization, it may affect the employee's work engagement. The continued study age and work engagement that confirm the high levels of work engagement in older employees such as this study are necessary to change the perception and remove negative stereotypes.

\section{REFERENCES}

Avery, D.R., McKay, P.F., \& Wilson, D.C. (2007). Engaging the aging workforce: The relationship between perceived age similarity, satisfaction with coworkers, and employee engagement. Journal of Applied Psychology, 92(6), 1542-1556. DOI: 10.1037/0021-9010.92.6.1542

Bakker, A.B., Albrecht, S.L., \& Leiter, M.P. (2011). Work engagement: Further reflections on state of play. European Journal of Work and Organizational Psychology, 20(1), 74-88. https://doi.org/10.1080/1359432X.2010.546711

Bakker, A.B., \& Demerouti, E. (2007). The job demands-resources model: state of the art. Journal of Managerial Psychology, 22(3), 309-328.

Bal, P.M., \& De Lange, A.H. (2015). From flexibility human resource management to employee engagement and perceived job performance across the lifespan: A multisample study. Journal of Occupational and Organizational Psychology, 88, 126-154. DOI:10.1111/joop. 12082.

Bal, P.M., \& Kooij, D. (2011). The relations between work centrality, psychological contracts, and job attitudes: The influence of age. European Journal of Work and Organizational Psychology, 20(4), 497-523. https://doi.org/10.1080/13594321003669079

Bayl-Smith, P.H., \& Griffin, B. (2014). Age discrimination in the workplace: Identifying as a late-career worker and its relationship with engagement and intended retirement age. Journal of Applied Social Psychology, 44, 588-599. https://doi.org/10.1111/jasp.12251

Beutell, N.J., \& Wittig-Berman, U. (2008). Work-family conflict and work-family synergy for generation $\mathrm{X}$, baby boomers, and satisfaction outcomes. Journal of Managerial Psychology, 23, 507-523.

Cennamo, L., \& Gardner, D. (2008). Generational differences in work values, outcomes and personorganizational values fit. Journal of Managerial Psychology, 23(8), 891-906. 
Chalofsky, N., \& Krishna, V. (2009). Meaningfulness, commitment, and engagement: The intersection of a deeper level of intrinsic motivation. Advances in Developing Human Resources, 11, 168-188. doi: $10.1177 / 1523422309333147$

Cuddy, A.J.C., Norton, M.I., \& Fiske, S.T. (2005). This old stereotype: the stubbornness and pervasiveness of the elderly stereotype. Journal of Social Issues, 61, 265-283.

D’Amato, A., \& Herzfeldt, R. (2008). Learning orientation, organizational commitment and talent retention across generations: A study of European managers. Journal of Managerial Psychology, 23(8), 929-953.

Deloitte. (2014). Global human capital trends 2014: Engaging the 21st-century workforce. Deloitte University Press. Retrieved from http://dupress.com/ wpcontent/uploads/2014/04/GlobalHumanCapitalTrends_2014.pdf

Demerouti, E., Mostert, K., \& Bakker, A.B. (2010). Burnout and work engagement: a thorough investigation of the independency of both constructs. Journal of Occupational Health Psychology, 15(3), 209.

Desmette, D., \& Gaillard, M. (2008). When a "worker" becomes an "older worker". Career Development International, 13(2), 168-185. https://doi.org/10.1108/13620430810860567

Dordoni, P., \& Argentero, P. (2015). When age stereotypes are employment barriers: a conceptual analysis and a literature review on older workers stereotypes. Ageing International, 40(4), 393412.

Douglas, S., \& Roberts, R.A. (in press). Employee age and the impact on work engagement. Strategic HR Review. DOI 10.1108/SHR-05-2020-0049

Foster, J.D., Campbell, W.K., \& Twenge, J.M. (2003). Individual differences in narcissism; Inflated selfviews across the lifespan and round the world. Journal of Research in Personality, 37, 469-486.

Fredrickson, B.L. (2001). The role of positive emotions in positive psychology: The broaden-and-build theory of positive emotions. American Psychologist, 56, 218-226.

Gilleard, C. (2004). Cohorts and generations in the study of social change. Social Theory and Heath, 2, 106-119.

Gruman, J.A., \& Saks, A.M. (2011). Performance management and employee engagement. Human Resource Management Review, 21, 123-136. doi:10.1016/j.hrmr.2010.09.004

Haley, L.M., Mostert, K., \& Els, C. (2013). Burnout and work engagement for different age groups: Examining group-level differences and predictors. Journal of Psychology in Africa, 23(2), 283295.

Hassell, B., \& Perrewé, P. (1993). An Examination of The Relationship Between Older Workers' Perceptions of Age Discrimination and Employee Psychological States. Journal of Managerial Issues, 5(1), 109-120. Retrieved from www.jstor.org/stable/40604173

Hirschfeld, R.R., \& Field, H.S. (2000). Work centrality and work alienation: Distinct aspects of a general commitment to work. Journal of Organizational Behavior, 21(7), 789-800. doi:10.1002/10991379(200011)21:73.0.CO;2-W

Hobfoll, S.E. (1989). Conservation of resources; A new attempt at conceptualizing stress. American Psychologist, 44(3), 513-524.

Hobfoll, S.E. (2001). The influence of culture, community, and the nested-self in the stress process: Advancing conservation of resources theory. Applied Psychology, 50(3), 337-421. https://doi.org/10.1111/1464-0597.00062

Hobfoll, S.E. (2002). Social and psychological resources and adaptation. Review of General Psychology, 6, 307-324.

Hobfoll, S.E., \& Shirom, A. (2001). Handbook of organizational behavior. Revised and Expanded.

Hobfoll, S.E., Johnson, R.J., Ennis, N., \& Jackson, A.P. (2003). Resource loss, resource gain, and emotional outcomes among inner city women. Journal of Personality and Social Psychology, 84, 632-643.

Hoole, C., \& Bonnema, J. (2015). Work engagement and meaningful work across generational cohorts. SA Journal of Human Resource Management, 13(1), 1-11. 
James, J.B., Besen, E., Matz-Costa, C., \& Pitt-Catsouphes, M. (2012). Just do it? ... Maybe not! Insights on activity in later life from the Life \& Times in an Aging Society Study. Chestnut Hill, MA:

Sloan Center on Aging \& Work, Boston College. Retrieved August 20, 2014, from http://www.bc.edu/content/dam/fi les/centers/ioa/pdf/EAWA_JustDoIt.pdf

Japan Statistics Bureau. (2013). Current population estimates as of October 1, 2013. Retrieved from http://www.stat.go.jp/english/data/jinsui/2013np/index.htm\#a15k25-a

Jones, J.S., Murray, S.R., \& Tapp, S.R. (2018). Generational differences in the workplace. Journal of Business Diversity, 18(2), 88-97.

Kahn, W.A. (1990). Psychological conditions of personal engagement and disengagement at work. Academy of Management Journal, 33, 692-724.

Kahn, W.A. (1992). To be fully there: Psychological presence at work. Human Relations, 45, 321-349.

Kim, N., \& Kang, S. (2017). Older and more engaged: The mediating role of age-linked resources on work engagement. Human Resource Management, 57(5), 731-746. DOI: 10.102/hrm.21802

Kular, S., Gatenby, M., Rees, C., Soane, E., \& Truss, K. (2008). Employee engagement: A literature review. Kingston University, London.

Lamont, R.A., Swift, H.J., \& Abrams, D. (2015). A review and meta-analysis of age-based stereotype threat: Negative stereotypes, not facts, do the damage. Psychology and Aging, 30(1), 180193. https://doi.org/10.1037/a0038586

Levy, S.R., \& Macdonald, J.L. (2016). Progress on understanding ageism. Journal of Social Issues, 72(1), 5-25.

Lipnic, V.A. (2018). The state of age discrimination and older workers in the US 50 years after the Age Discrimination in Employment Act (ADEA). Washington, DC: US Equal Employment Opportunity Commission. Retrieved from tinyurl. com/yyweslnz

Macey, W.H., \& Schneider, B. (2008). The meaning of employee engagement. Industrial and organizational Psychology, 1(1), 3-30.

Maslach, C., \& Leiter, M.P. (2008). The truth about burnout: How organizations cause personal stress and what to do about it. John Wiley \& Sons.

Matos, K., \& Galinsky, E. (2014). 2014 national study of employers. New York, NY: Families and Work Institute. Retrieved from http://www. familiesandwork.org/2014-national-study-of-employers/

McCann, R., \& Giles, H. (2002). Ageism in the workplace: A communication perspective. In T. D. Nelson (Ed.), Ageism: Stereotyping and prejudice against older persons (pp. 163-199). The MIT Press.

Meade, A.W., Michels, L.C., \& Lautenschlager, G.J. (2007). Are Internet and paper-and-pencil personality tests truly comparable? An experimental design measurement invariance study. Organizational Research Methods, 10(2), 322-345.

NG, T.W., \& Feldman, D.C. (2010). The relationships of age with job attitudes: A meta-analysis. Personnel Psychology, 63(3), 677-718. https://doi.org/10.1111/j.1744-6570.2010.01184.x

Owens, B.P., Baker, W.E., Sumpter, D.M., \& Cameron, K.S. (2016). Relational energy at work: Implications for job engagement and job performance. Journal of Applied Psychology, 101(1), 35-49. http://dx.doi.org/10.1037/ap10000032

Parry, E., \& Urwin, P. (2011). Generational differences in work values: A review of theory and evidence International Journal of Management Reviews, 13, 79-96.

Pitt-Catsouphes, M., \& Matz-Costa, C. (2008). The multi-generational workforce: Workplace flexibility and engagement. Community, Work, \& Family, 11(2), 215-229. https://doi.org/10.1080/13668800802021906

Pocnet, C., Antonietti, J.P., Massoudi, K., Györkös, C., Becker, J., de Bruin, G.P., \& Rossier, J. (2015). Influence of individual characteristics on work engagement and job stress in a sample of national and foreign workers in Switzerland. Swiss Journal of Psychology, 74(1), 17.

Posthuma, R.A., \& Campion, M.A. (2009). Age stereotypes in the workplace: Common stereotypes, moderators, and future research directions. Journal of management, 35(1), 158-188. 
Rigotti, T. (2009). Enough is enough? Threshold models for the relationship between psychological contract breach and job-related attitudes. European Journal of Work and Organizational Psychology, 18(4), 442-463. https://doi.org/10.1080/13594320802402039

Roberts, R.A. (in press). From Snacking on Diversity and Inclusion to Systemic Organizational Consumption. Strategic HR Review. DOI 10.1108/SHR-05-2020-0048

Robinson, D., Perryman, S., \& Hayday, S. (2004). The drivers of employee engagement. Report No. 408. Institute for Employment Studies. Retrieved from http://www.employmentstudies.co.uk/summary/ summary.php?id=408

Roscigno, V.J. (2010). Ageism in the American Workplace. Contexts, 9(1), 16-21. https://doi.org/10.1525/ctx.2010.9.1.16

Rousseau, D.M. (1989). Psychological and implied contracts in organizations. Employee Responsibilities and Rights Journal, 2(2), 121-139.

Rousseau, D.M. (1990). New hire perception of their own and their employer's obligations: A study of psychological contracts. Journal of Organizational Behavior, 11, 389-400.

Ryder, N.B. (1965). The cohort as a concept in the study of social change. American Sociology Review, 30, 843-861.

Sayers, R. (2007). The right staff from X to Y: Generational change and professional development in future academic libraries. Library Management, 28(8/9), 474-487.

Schaufeli, W.B., \& Bakker, A.B. (2004). Job demands, job resources, and their relationship with burnout and engagement: A multi-sample study. Journal of Organizational Behavior, 25, 293-315. 10.1002/(ISSN)1099-1379.

Schaufeli, W.B., Bakker, A.B., \& Salanova, M. (2006). The measurement of work engagement with a short questionnaire a cross-national study. Educational and Psychological Measurement, 66, 701-716

Schaufeli, W., Salanova, M., Gonzalez-Roma, V., \& Bakker, A. (2002). The measurement of engagement and burnout: A two sample confirmatory factor analytic approach. Journal of Happiness Studies, 3, 71-92.

Sessa, V.I., Kabacoff, R.I., Deal, J., \& Brown, H. (2007). Generational differences in leader values and leadership behaviors. Psychologist-Manager Journal, 10, 47-74.

Shuck, B. (2011). Integrative literature review: Four emerging perspectives of employee engagement: An integrative literature review. Human Resource Development Review, 10(3), 304-328.

Smola, K. W., \& Sutton, C. (2002). Generational differences: Revisiting generational work values for the new millennium. Journal of Organizational Behavior, 23, 363-382.

Snape, E., \& Redman, T. (2003). Too old or too young? The impact of perceived age discrimination. Human Resource Management Journal, 13(1), 78-89. https://doi.org/10.1111/j.17488583.2003.tb00085.x

Sweetman, D., \& Luthans, F. (2010). The power of positive psychology: Psychological capital and work engagement. In A.B. Bakker \& M.P. Leiter (Eds.), Work engagement: A handbook of essential theory and research (pp. 54-68). New York: Psychology Press.

Tempest, S., Barnatt, C., \& Coupland, C. (2002). Grey advantage - New strategies for the old. Long Range Planning, 35, 475-492.

The National Institute for Occupational Safety and Health (NIOSH). (2015). Productive aging and work.

Toossi, M., \& Torpey, E. (2017). Older workers: Labor force trends and career options. Retrieved from https://www.bls.gov/careeroutlook/2017/article/older-workers.htm

Towers Perrin. (2005). The business case for workers age 50+: Planning for tomorrow's talent needs in today's competitive environment. Washington, DC: AARP. Retrieved from http://assets.aarp.org/rgcenter/ econ/workers fi fty plus.pdf

Truss, C., Shantz, A., Soane, E., Alfes, K., \& Delbridge, R. (2013). Employee engagement, organizational performance and individual well-being: exploring the evidence, developing the theory. The International Journal of Human Resource Management, 24(14), 2657-2669. doi: 10.1080/09585192.2013.798921 
Twenge, J.M., \& Campbell, S.M. (2008). Generational differences in psychological traits and their impact on the workplace. Journal of Managerial Psychology, 23, 862-877.

Twenge, J. M. (2010). A review of the empirical evidence on generational differences in work attitudes. Journal of Business and Psychology, 25, 201-210.

United Nations Department of Economic and Social Affairs. (n.d.). World population ageing 2019 highlights. Retrieved from https://www.un.org/development/desa/pd/sites/www.un.org.development.desa.pd/files/files/docu ments/2020/Jan/worldpopulationageing2019-highlights.pdf

Veth, K.N., Korzilius, H., Van der Heijden, B., Emans, B., \& De Lange, A.H. (2019). Which HRM practices enhance employee outcomes at work across the life-span? The International Journal of Human Resource Management, 30(19), 2 777-2808. https://doi.org/10.1080/09585192.2017.1340322

Villegas, S. (2020). Different yet similar: Multi-generational professionals and their sentimentality towards reciprocity. Journal of Business Divers, 20(1), 66-79. https://doi.org/10.33423/jbd.v20i1.2708

Westman, M., Hobfoll, S.E., Chen, S., Davidson, O.R., \& Laski, S. (2004). Organizational stress through the lens of conservation of resources (COR) theory. In P.L. Perrewe \& D.C. Ganser (Eds.), Exploring Interpersonal Dynamics (Research in Occupational Stress and Well Being, 4) (pp. 167220). https://doi.org/10.1016/S1479-3555(04)04005-3

Xanthopoulou, D., Bakker, A.B., Demerouti, E., \& Schaufeli, W.B. (2007). The role of personal resources in the job demands-resources model. International Journal of Stress Management, 14(2), 121141. https://doi.org/10.1037/1072-5245.14.2.121 